\title{
Test Excavations at Site 41LK269 Live Oak County, Texas
}

Glenn T. Goode

Follow this and additional works at: https://scholarworks.sfasu.edu/ita

Part of the American Material Culture Commons, Archaeological Anthropology Commons, Environmental Studies Commons, Other American Studies Commons, Other Arts and Humanities Commons, Other History of Art, Architecture, and Archaeology Commons, and the United States History Commons

Tell us how this article helped you.

This Article is brought to you for free and open access by the Center for Regional Heritage Research at SFA ScholarWorks. It has been accepted for inclusion in Index of Texas Archaeology: Open Access Gray Literature from the Lone Star State by an authorized editor of SFA ScholarWorks. For more information, please contact cdsscholarworks@sfasu.edu. 


\section{Test Excavations at Site 41LK269 Live Oak County, Texas}

\section{Licensing Statement}

This is a work produced for the Texas Department of Transportation (TxDOT) by the report producer. TxDOT and the report producer jointly own all rights, title, and interest in and to all intellectual property developed under TXDOT's contract with the report producer. The report may be cited and brief passages from this publication may be reproduced without permission provided that credit is given to both TxDOT and the report producer. Permission to reprint an entire chapter, section, figures or tables must be obtained in advance from either the Supervisor of the Archeological Studies Branch, Environmental Affairs Division, Texas Department of Transportation, 125 East 11th Street, Austin, Texas, 78701 or from the report producer. 
TEST EXCAVATIONS AT SITE 41LK269

LIVE OAK COUNTY, TEXAS

By

Glenn T. Goode

Texas

State Department of Highways and Public Transportation

Highway Design Division

October 1986 


\section{ABSTRACT}

Archaeological site 41LK269 is a prehistoric open campsite located on a Pleistocene terrace remnant of the Nueces River near George West, Texas. The small portion of the site which remains within the right-of-way of US Highway 59 produced a meager sample of aboriginal materials. The cultural remains, devoid of diagnostic artifacts, consist of lithic artifacts and fire-cracked rock. The absence of diagnostic materials precludes an accurate assessment of the occupation time frame. The recovery indicates that that portion of the site which occurs within the highway right-of-way does not merit nomination to the National Register of Historic Places or designation as a State Archeological Landmark. The site extends for several hundred meters along the terrace outside the right-of-way, and a determination of National Register significance and/or State Archeological Landmark status was not made on this, larger portion of the site. 
TABLE OF CONTENTS

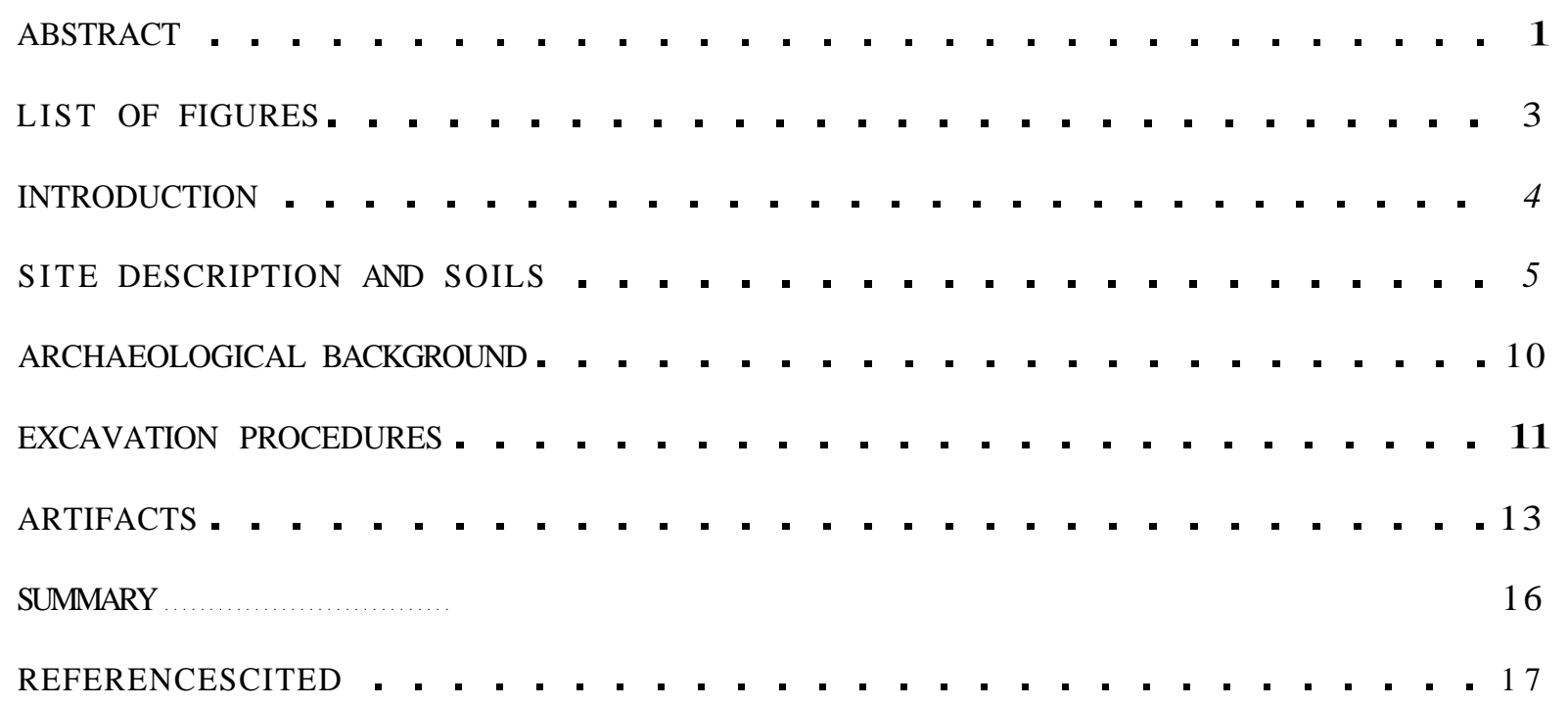




\section{LIST OF FIGURES}

FIGURE 1. Project and site location in Live Oak County. Texas . . . . 6

FIGURE 2. Contour map of Site 41LK269. showing excavation units and backhoe trenches. . . . . . . . . . . . . . . . 7

FIGURE 3. Soil profile from Site 41LK269. . . . . . . . . . . . . . . 8

FIGURE 4. Artifacts from Site 41LK269. . . . . . . . . . . . . 12 


\section{INTRODUCTION}

Archaeological testing of Site 41LK269 was conducted by Glenn T. Goode of the State Department of Highways and Public Transportation (SDHPT), with support personnel from the George West SDHPT residency during the period May 21 t o May 30, 1986. Approximately 175 man-hours were expended on the project. Fieldwork was performed in accordance with Procedures for the Protection of Historic and Cultural Properties (36 CFR, Part 800), procedures prescribed by law and endorsed by the Federal Highway Administration.

The fieldwork objectives were to determine the content and extent of cultural remains, the potential of eligibility for nomination to the National Register of Historic Places, and the potential for nomination as a State Archeological Landmark. Investigation of the site area was prompted by scheduled improvement of the Nueces River bridge on US Highway 59. The site was recorded by Daymond Crawford of the SDHPT in May 1984. Most of the site present within the highway right-of-way had been destroyed by the original road construction. 


\section{SITE DESCRIPTION AND SOILS}

Site 41LK269 is situated on a Pleistocene terrace remnant approximately .5 kilometer west of the Nueces River (Fig. 1). The overall site area is large, extending as a 100-meter-wide band southward from the US 59 right-ofway for a distance of several hundred meters (Figs. 1 and 2). However, the area subject to this investigation is rather small: a 3- to 4-meter-wide strip running along the south right-of-way fence (Fig. 2).

An unknown, but much greater, portion of the site was destroyed by the construction of US 59. The higher portion of the terrace and Site 41LK269 probably sloped downward gradually toward the north right-of-way fence, beyond which the terrace flattens out into pastureland. No artifacts were visible along or beyond the fence.

Over much of the site cultural material occurs as a relatively thin mantle, being most abundant from the eroded terrace edge westward to its highest point. The elevated physiographic setting precluded alluvial deposition during the Holocene, leaving the cultural remains to be slowly buried by colluvial and eolian action.

A soil profile from the site is shown in Fig. 3. Actually, this profile is typical only of Test Units 2 and 3 . The deposit containing artifacts is much thinner over a great majority of the site, averaging less than $30 \mathrm{~cm}$ in depth. In Test Units 2 and 3 , the fairly recent upper zone of yellowish brown sandy loam contained few artifacts. The underlying zone of homogeneous brown sandy loam is the major artifact-bearing deposit, but no discrete cultural lenses were apparent within it. The third zone is a lighter brown loam with greater silt content. Although artifacts were present in this zone, they were very sparse and decreased with depth. 
This Page Redacted Per THC Policy 


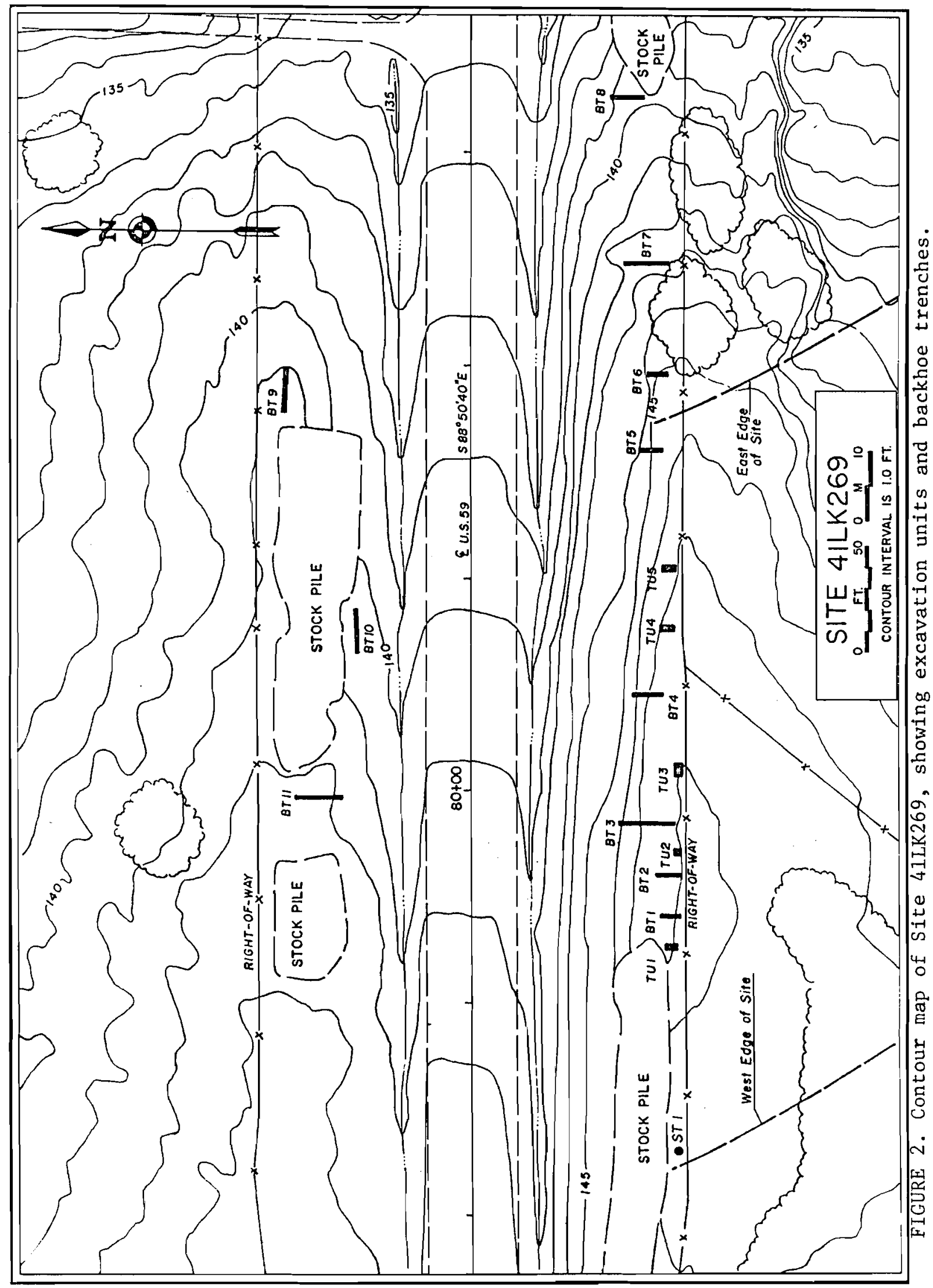




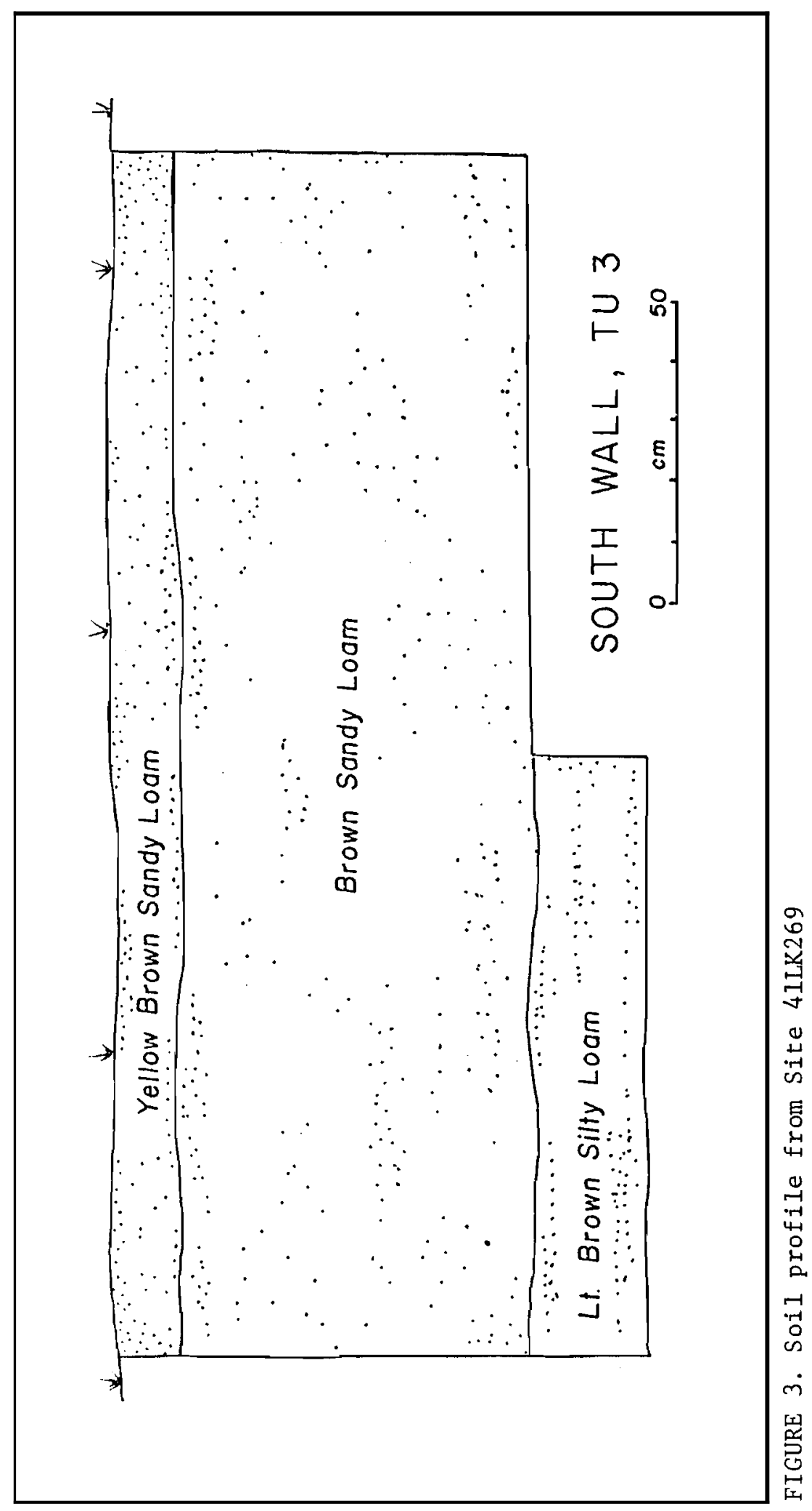


In Test Units 1, 4, and 5, the brown sandy loam had greater clay content from 10 to $30 \mathrm{~cm}$. At an average depth of $30 \mathrm{~cm}$ the clay content increased substantially. This matrix was a light brown clay loam containing' no artifacts.

Backhoe Trenches 2 and 4 revealed that the deeper sandy loam deposit present in Test Units 2 and $\mathbf{3}$ and Backhoe Trench $\mathbf{3}$ was an isolated phenomenon. This soil was absent in these and all other backhoe trenches except Backhoe Trench 3. A possible explanation involves an erosional episode of the terrace, perhaps during the early Holocene, with subsequent differential deposition over an uneven surface. Abundant vegetation in the area includes mesquite, hackberry, elm, live oak, Texas persimmon, agarita, blackbrush, whitebrush, and cactus. 


\section{ARCHAEOLOGICAL BACKGROUND}

A great majority of archaeological investigations in this area have occurred since 1960. One of the earliest surveys of the Choke Canyon area was conducted by Wakefield (Wakefield 1968) of the Texas Archeological Salvage Project. Archaic through Historic materials were recovered from the 18 sites recorded. Numerous investigations by Hester document the association of Late Prehistoric and Historic ceramics (Hester 1968b), intrusive ceramics in the Dimmit County area (Hester and Hill 1969), and the presence of Paleo-Indian materials along San Miguel Creek (Hester 1968a). Other materials from Frio River sites also have been documented by Hester (1969b).

Since the early 1970 s much work has been completed in the Chaparrosa Ranch area of Zavala County (Hester and Hill 1970; Hester 1978) and the Choke Canyon area of McMullen and Live Oak Counties (Hall, Black, and Graves 1982). Several hundred sites were recorded here but only a few were investigated extensively. Middle and Late Archaic materials, as well as Late Prehistoric materials, were abundant but relatively little Early Archaic and Paleo-Indian evidence was found (Hall, Black, and Graves 1982).

A large burial and habitation site in Live Oak County (41LK28) was excavated by the SDHPT in 1977-1978. A wide range of Archaic materials was recovered; of particular interest was the presence of an extensive Late Archaic occupation associated with the cemetery from the same time period. 


\section{EXCAVATION PROCEDURES}

Test excavation of Site 41LK269 was performed by both manual and mechanical means. A total of 5 test units was excavated to sterile soil with shovel, pick, and trowel. Of these, 4 units measured 1 by 2 meters and 1 unit (Test Unit 2) measured 1 by 1 meter. Vertical increments were consistently $10 \mathrm{~cm}$. The sandy loam soil was extremely hard-packed by road machinery in places, requiring the application of water prior to excavation. The soil matrix was screened through .25-in. mesh hardware cloth. A 11 cultural material was placed in appropriately labeled bags.

Test units were placed at varying intervals as deemed necessary to provide an adequate sample. Test Units 4 and 5 were more closely spaced in an area with a higher density of artifacts visible on the surface. A bifacial tool (Fig. 4A) was found on the surface near Test Unit 4. The hand-excavated units were interspersed with backhoe trenches to readily provide profiles and thoroughly test the subsurface. In all, 11 backhoe trenches were excavated. Several shovel tests were randomly placed to locate approximate 1 imits of the site. 


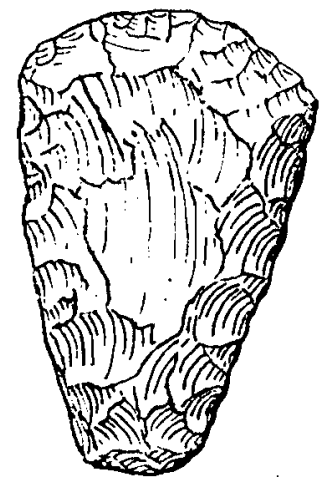

A

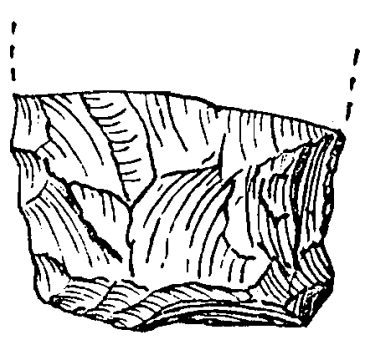

$D$

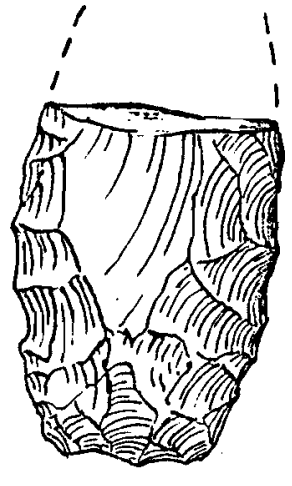

B

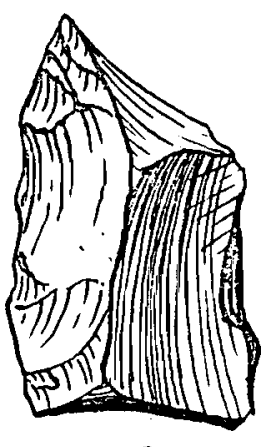

E
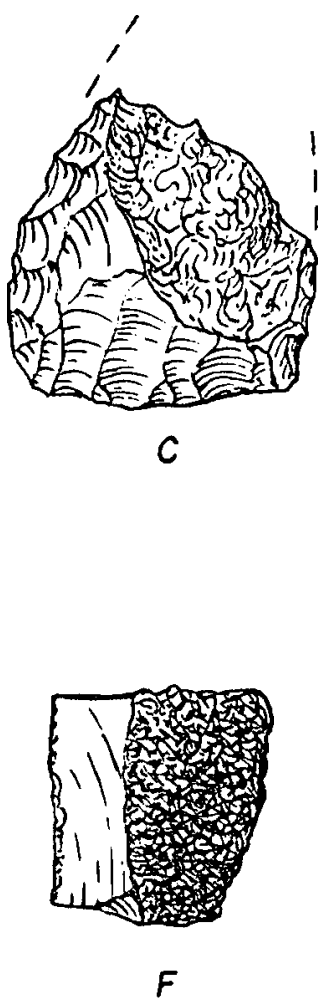

$F$

FIGURE 4. Artifacts from Site 4lLK269. A, adze-like biface; B-D, possible dart point/knife fragments; E, outrepassé flake; F, trimmed/nicked flake. 


\section{ARTIFACTS}

The artifact assemblage recovered at 41LK269 (Table 1) is made up completely of lithic materials. A total of 745 specimens came from the 5 test units. The identified artifact classes are: flakes and fragments - 727 specimens; cores and fragments - 11 specimens; bifaces - 6 specimens; and outrepasse biface fragments - 2 specimens. Although the entire sample could be classified as lithic debitage, several possible tools are present.

An intensive but uncontrolled surface collection produced an additional 355 lithic items. In this collection a single biface stands out among the flake debitage. This piece is a gouge or adze.

Lithic raw materials for both tools and hearthstones likely were obtained from local gravel deposits. Such material was available from the Pleistocene terrace, although in relatively small size. Many similar sources probably exist along the Nueces terraces. Chert is by far the predominate material for tools. Also identified are 27 silicified wood flakes and 5 quartzite flakes. Probably, at least half this number were missed in the brief analysis. Chert was also commonly used as hearthstdnes, but a soft sandstone makes up at least one-half of the fire-cracked rock sample.

A brief analysis of the flake debitage is aimed at identifying types of tools used and stages of reduction present. The flake sample is sorted into hard, soft, and undetermined hammer categories for the specimens with striking platforms. From the excavated sample, 362 specimens retain the striking platform. Of these, $24 \%$ have characteristics typical of hardhammer percussion, $60 \%$ are soft-hammer, and $16 \%$ were produced by undetermined means. The figures from the surface sample are comparable: hardhammer - 24\%; soft-hammer - 55\%; undetermined - $21 \%$. 
TABLE 1. Artifact provenience from Site $41 \mathrm{LK} 269$.

\begin{tabular}{|c|c|c|c|c|c|c|c|c|c|c|c|c|c|c|c|}
\hline Provenience & 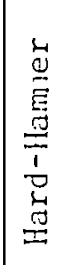 & 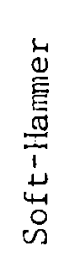 & 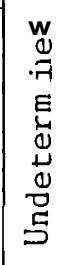 & 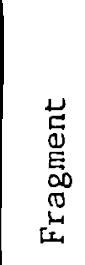 & 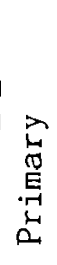 & 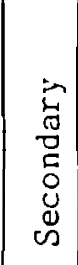 & 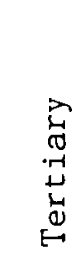 & 㫕 & 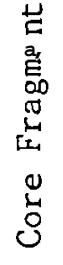 & $\begin{array}{l}0 \\
0 \\
0 \\
4 \\
-1 \\
0\end{array}$ & $\left|\begin{array}{l}0 \\
0 \\
0 \\
0 \\
0 \\
0 \\
0 \\
0 \\
3 \\
0\end{array}\right|$ & $\begin{array}{l}3 \\
0 \\
3 \\
\dot{0} \\
\dot{\pi} \\
\dot{n}\end{array}$ & 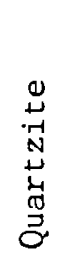 & 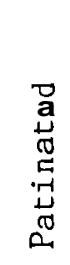 & 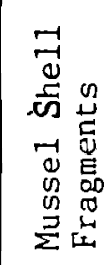 \\
\hline $\begin{array}{c}\text { Test Unit } 1 \\
\text { Level } 1 \\
2 \\
3 \\
\text { Unit Total }\end{array}$ & $\begin{array}{r}4 \\
15 \\
\\
19\end{array}$ & $\begin{array}{r}1 \\
24 \\
35\end{array}$ & $\begin{array}{l}2 \\
5\end{array}$ & $\begin{array}{r}9 \\
36 \\
1 \\
46\end{array}$ & $\begin{array}{l}4 \\
4\end{array}$ & $\begin{array}{r}4 \\
12 \\
16\end{array}$ & $\begin{array}{r}22 \\
64 \\
1 \\
87\end{array}$ & 1 & $\begin{array}{l}1 \\
1 \\
2\end{array}$ & & 1 & $\begin{array}{l}1 \\
1\end{array}$ & & 2 & \\
\hline $\begin{array}{c}\text { Test Unit } 2 \\
\text { Level } 1 \\
2 \\
3 \\
4 \\
5 \\
6 \\
7 \\
8 \\
9 \\
\text { Unit Total }\end{array}$ & $\begin{array}{r}2 \\
2 \\
2 \\
1 \\
15\end{array}$ & $\begin{array}{c}7^{1} \\
\\
1 \\
2 \\
6 \\
7 \\
3 \\
27\end{array}$ & $\mid \begin{array}{r}1^{2} \\
1 \\
3\end{array}$ & $\begin{array}{c}4 \\
1 \\
4 \\
4 \\
5 \\
6 \\
1 \\
6 \\
3 \\
54\end{array}$ & $\begin{array}{l}1 \\
1 \\
\\
1 \\
2 \\
5\end{array}$ & \begin{tabular}{|c}
$\quad 4$ \\
5 \\
1 \\
2 \\
2 \\
3 \\
4 \\
4 \\
1 \\
22
\end{tabular} & $\begin{array}{r}6 \\
7 \\
5 \\
3 \\
7 \\
8 \\
20 \\
20 \\
0 \\
4 \\
80\end{array}$ & & $\begin{array}{l}1 \\
2\end{array}$ & & & $\begin{array}{l}1 \\
1\end{array}$ & 1 & & $\begin{array}{r}1 \\
2 \\
2 \\
2 \\
1 \\
4 \\
5 \\
3 \\
18\end{array}$ \\
\hline $\begin{array}{c}\text { Test Unit } 3 \\
\text { Level } 1 \\
2 \\
3 \\
4 \\
5 \\
6 \\
7 \\
8 \\
9 \\
\text { Unit Total }\end{array}$ & $\begin{array}{l}5 \\
2 \\
\\
1 \\
3 \\
4 \\
3\end{array}$ & $\begin{array}{r}1 \\
10 \\
2 \\
3 \\
\\
2 \\
2 \\
3 \\
3 \\
26\end{array}$ & $\begin{array}{l}1 \\
3\end{array}$ & $\begin{array}{r}2 \\
11 \\
4 \\
7 \\
2 \\
\\
5 \\
4 \\
4 \\
39\end{array}$ & & $\begin{array}{r}1 \\
5 \\
3 \\
2 \\
2 \\
3 \\
1 \\
1 \\
18\end{array}$ & $\begin{array}{r}3 \\
24 \\
5 \\
9 \\
1 \\
2 \\
12 \\
10 \\
6 \\
72\end{array}$ & 1 & & & & $\begin{array}{l}1 \\
7\end{array}$ & & $\begin{array}{l}1 \\
2 \\
6\end{array}$ & $\begin{array}{r}1 \\
4 \\
3 \\
2 \\
10\end{array}$ \\
\hline $\begin{array}{c}\text { Test Unit } 4 \\
\text { Level } 1 \\
2 \\
3 \\
4 \\
\text { Unit Total }\end{array}$ & $\begin{array}{r}8 \\
8 \\
8 \\
\\
24\end{array}$ & $\begin{array}{r}6 \\
4 \\
27 \\
2 \\
86\end{array}$ & $\begin{array}{r}1 \\
7 \\
4 \\
12\end{array}$ & $\begin{array}{r}29 \\
67 \\
31 \\
8 \\
135\end{array}$ & 1 & $\begin{array}{r}6 \\
26 \\
10 \\
3 \\
45\end{array}$ & $\begin{array}{r}48 \\
97 \\
59 \\
7 \\
211\end{array}$ & $\begin{array}{l}1 \\
1\end{array}$ & & 2 & 1 & $\begin{array}{l}1 \\
4 \\
5\end{array}$ & $\begin{array}{l}1 \\
1 \\
2\end{array}$ & $\begin{array}{r}4 \\
9 \\
4 \\
17\end{array}$ & $\begin{array}{r}1 \\
20 \\
18 \\
3 \\
39\end{array}$ \\
\hline $\begin{array}{c}\text { Test Unit } 5 \\
\text { Level } 1 \\
2 \\
3 \\
\text { Unit Total }\end{array}$ & $\begin{array}{r}8 \\
13 \\
2 \\
23\end{array}$ & $\begin{array}{l}18 \\
23 \\
4 \\
45\end{array}$ & $\begin{array}{l}8 \\
6 \\
3 \\
17\end{array}$ & $\begin{array}{r}33 \\
36 \\
2 \\
81\end{array}$ & $\begin{array}{l}1 \\
1\end{array}$ & $\begin{array}{r}14 \\
14 \\
4 \\
32\end{array}$ & $\begin{array}{r}52 \\
63 \\
17 \\
132\end{array}$ & $\begin{array}{l}2 \\
2\end{array}$ & & $\begin{array}{l}1 \\
1 \\
1 \\
3\end{array}$ & & $\begin{array}{l}3 \\
2 \\
2 \\
7\end{array}$ & & $\begin{array}{l}1 \\
4 \\
5\end{array}$ & $\begin{array}{r}1 \\
6 \\
12 \\
19\end{array}$ \\
\hline Surface & 42 & 98 & 37 & 177 & 6 & 111 & 237 & & & 1 & & 4 & 2 & 12 & \\
\hline
\end{tabular}


Although a large majority of the flake debitage is classified as tertiary, there are sufficient core fragments and decorticate flakes to state that all stages of core reduction occurred at the site. The biface sample is too small, 6 of the 7 fragments are final stage, to make definite statements about biface reduction. At least the finishing of bifaces was attempted here.

The relatively small sample of bifaces and other possible tools was unexpected, given the relatively large debitage sample. Only 1 complete biface (Fig. 4A) was recovered. This specimen has a unifacially beveled bit typical of small adze-like tools common to the area. Both lateral edges are bifacially beveled but are not dulled. Moderately heavy patina is present on both faces. Thickness is $8 \mathrm{~mm}$.

Specimens B, C, and D (Fig. 4) average $7 \mathrm{~mm}$ in thickness and could have been dart points or small knives. Their fragmentary nature precludes any statement regarding shape or age.

Specimen E (Fig. 4) is an outrepasse, or "overshot, "flake from a fairly large biface nearing the final stage of reduction. Other possible tools include 2 thin flakes with trimmed/nicked edges (Fig. 4F) and a thick flake with unifacial thinning, possibly intended for scraping functions. 


\section{SUMMARY}

Archaeological site 41LK269 appears to be a typical high terraceupland site of the region. Relatively abundant lithic artifacts and firecracked rock are present but perishable materials are rare. Approximately 90 small fragments of mussel shell were recovered, but bone and charcoal were absent. Intact fire hearths or related features were not recognized at the site, the small fire-cracked rock sample recovered being scattered and mixed through the deposit. Slow soil deposition and frequent reuse of the site probably were factors not conducive to preservation of features.

Since no diagnostic tools or means of dating were recovered, only a general statement regarding the time period of occupation is possible. Given the physiographic setting, high terrace, and large size of occupied area, it can be speculated that repeated occupation probably occurred through much of the Archaic and Late Prehistoric. Early Archaic and PaleoIndian occupations might be less likely, but possible.

The meager information recovered by this project should not be considered typical of the 41LK269 site area. Very likely, much more intensively occupied areas exist, the investigation of which could make a more significant contribution to the local prehistory. The extremely small site area which remains intact within the US 59 right-of-way and the dearth of significant artifacts and features preclude any consideration of further investigation at this site.

Therefore, that portion of Site 41LK269 within the right-of-way is not considered eligible for nomination to the National Register of Historic Places nor worthy of State Archeological Landmark status. 


\section{REFERENCES CITED}

Hall, Grant D., Stephen L. Black, and Carol Graves

1982 Archaeological Investigations at Choke Canyon Reservoir, South Texas: The Phase I Findings. Choke Canyon Series 5. Center for Archaeological Research, The University of Texas at San Antonio.

Hester, Thomas R.

1968a Paleo-Indian Artifacts from Sites along San Miguel Creek:

Frio, Atascosa and McMullen Counties, Texas. Bulletin of the Texas Archeological Society 39:147-161.

1968b Notes on Some Pottery-Bearing Sites in Southern Texas. The Bull-Roarer, University of Texas Anthropological Society Newsletter 3(2):9-11.

1970 Metal Projectile Points from Southern Texas. The Record, Dallas Archeological Society 27:9-11.

Hester, Thomas R., and T. C. Hill, Jr.

1969 Mogollon Ceramics from Southern Texas. The Artifact 7(3): $11-15$.

1970 Archeological Research in Southern Texas in 1970. Texas Archeology $15(1): 4-5$.

Wakefield, W. W.

1968 Archeological Survey of Palmetto Bend and Choke Canyon Reservoir, Texas. Survey Report 5. Texas Archeological Salvage Project, The University of Texas at Austin. 